\title{
Primary culture of Zhikong scallop Chlamys farreri hemocytes as an in vitro model for studying host-pathogen interactions
}

\author{
Aichang Ji ${ }^{1}$, Xueyu Li ${ }^{1}$, Sha Fang ${ }^{1}$, Zhenkui Qin ${ }^{1}$, Changming Bai ${ }^{2}$, \\ Chongming Wang ${ }^{2}$, Zhifeng Zhang ${ }^{1, *}$
}

${ }^{1}$ Key Laboratory of Marine Genetics and Breeding (Ocean University of China), Ministry of Education, Qingdao 266003, PR China

${ }^{2}$ Division of Maricultural Organism Disease Control and Molecular Pathology, Yellow Sea Fisheries Research Institute, Chinese Academy of Fishery Sciences, Qingdao 266071, PR China

\begin{abstract}
Primary cultured cells can be a useful tool in studies on physiology, virology, and toxicology. Hemocytes play an important role in animal rapid response to pathogen invasion. In this study, an appropriate medium for primary culture of hemocytes of the bivalve Chlamys farreri was developed by adding $5 \%$ fetal bovine serum and $1 \%$ C. farreri serum to Leibovitz L-15 medium. These primary cultured hemocytes were maintained for more than $40 \mathrm{~d}$ in vitro and were classified into 3 types: (1) granulocytes containing numerous granules in the cytoplasm, (2) hyalinocytes with no or few granules, (3) a small percentage of macrophage-like cells. Furthermore, the primary cultured hemocytes were observed to be sensitive to bacterial and viral challenges. These hemocytes could phagocytose the bacterium Vibrio anguillarum, and presented cytopathic effects on the extracellular products (ECPs) of $V$. anguillarum; the mRNA level of $Q M$, which plays an important role in immune response, also significantly increased $12 \mathrm{~h}$ after infection. When these hemocytes were challenged with ostreid herpesvirus 1 (OsHV-1), virus particles and empty capsids in the cells infected for $48 \mathrm{~h}$ were observed by transmission electron microscopy, and the $Q M$ mRNA level increased significantly at $12 \mathrm{~h}$ and $24 \mathrm{~h}$ following OsHV-1 challenge. This primary culture system is available for $C$. farreri hemocytes which can be used in the future to study host-pathogen interactions.
\end{abstract}

KEY WORDS: Chlamys farreri · Cell culture · Hemocyte · Vibrio anguillarum - Ostreid herpesvirus 1 Resale or republication not permitted without written consent of the publisher

\section{INTRODUCTION}

Hemocytes are considered to be the main immune effector cells participating in innate immune responses such as phagocytosis, inflammation, and wound repair, and modulating organism homeostasis in mollusks (Sparks \& Morado 1988, Chu 2000). Based on their morphological and cytochemical features, mollusk hemocytes are mainly categorized into 2 types: granulocytes, with numerous granules in the cytoplasm, and hyalinocytes, with no or few granules (Hine 1999, Cima et al. 2000, Aladaileh et al. 2007, Donaghy et al. 2009, Astuya et al. 2015). Moreover, subpopulations of hyalinocytes and granulocytes are also observed in several mollusk species, such as the clam Ruditapes philippinarum (López et al. 1997, Cima et al. 2000, Lambert et al. 2003, 2007) and abalone Haliotis tuberculata (Hine 1999, Travers et al. 2008). In addition to the common granulocytes and hyalinocytes, a small quantity of 
large hyalinocytes possessing a phagocytic function are deemed to be macrophages in the Zhikong scallop Chlamys farreri (Sun \& Li 2001).

In vitro culture cell is an important tool for investigating physiology, virology, toxicology, and carcinogenesis (Zhang et al. 2011). In marine organisms, many cell lines of fish have been established and are commonly used in diagnosing and characterizing viral and bacterial pathogens as well as exploring pathogenic mechanisms (Fryer et al. 1992, Chen et al. 2004, Gong et al. 2011, Hasoon et al. 2011). However, no immortalized cell line in marine invertebrates has been established to date, although great efforts have been made over the last several decades (Rinkevich 2005, Yoshino et al. 2013, Cai \& Zhang 2014). Therefore, research has been devoted to establishing stable primary culture systems for related studies, including investigations of the propagation of white spot syndrome virus (WSSV) in primary cultured ovarian cells of the kuruma shrimp Marsupenaeus japonicus (Maeda et al. 2004); susceptibility of WSSV in vitro in primary cultured lymphoid cells from Penaeus monodon, Metapenaeus ensis, and Litopenaeus vannamei (Han et al. 2013, Li et al. 2014, Puthumana et al. 2015); electrophysiological analysis in primary cultured neurons of the crab Carcinus maenas and lobster Homarus americanus (Saver et al. 1999, Stepanyan et al. 2004); and genotoxicity and cytotoxicity of the antibacterial agent Triclosan in primary cultured hemocytes of the zebra mussel Dreissena polymorpha (Binelli et al. 2009a,b).

The Zhikong scallop C. farreri is an important commercial bivalve that is cultured widely along the coast of northern China. In this study, we established a primary culture system for hemocytes of $C$. farreri and investigated the sensitivity of these hemocytes to infection by Vibrio anguillarum, a common pathogen in scallop aquaculture (Zhou et al. 2011, Wang et al. $2012 a, b)$, and by ostreid herpesvirus 1 (OsHV-1), which can cause mass mortality of cultivated bivalves around the world (Renault et al. 1995, Le Deuff \& Renault 1999, Davison et al. 2005, 2009, EFSA 2010, Segarra et al. 2010, Bai et al. 2015, Barbosa Solomieu et al. 2015). Our data will be helpful in developing hemocyte cultures in vitro and understanding pathogenic mechanisms in marine mollusks.

\section{MATERIALS AND METHODS}

\section{Animals and sampling}

Adult scallops Chlamys farreri with a mean shell height of $6.28 \pm 0.43(\mathrm{SD}) \mathrm{cm}$ were collected from Shazikou bay (Qingdao, China) and maintained in filtered seawater (FSW, $14 \pm 2$ psu) for $2 \mathrm{~d}$. Hemolymph was extracted using a sterile syringe from $C$. farreri adductor muscle after the scallop shell and adductor muscle were decontaminated with a common swab soaked in $75 \%$ ethanol cotton. Part of the hemolymph was seeded onto plastic Petri dishes or 24-well plates (Nunc) for in vitro culture. Others were transferred to a sterile container overnight at $4^{\circ} \mathrm{C}$, and then centrifuged at $2000 \times g\left(20 \mathrm{~min}\right.$ at $\left.4^{\circ} \mathrm{C}\right)$. The supernatant was then filter-sterilized and labeled C. farreri serum (CFS), which was stored at $-20^{\circ} \mathrm{C}$ until use.

\section{Optimization of the medium}

To increase survival of the cultured C. farreri hemocytes, the medium was first optimized by supplementing fetal bovine serum (FBS, Hyclone) and CFS to the basic L15 medium (BM-L15, pH 7.2-7.4). BM-L15 medium consists of $13.7 \mathrm{~g} \mathrm{l}^{-1}$ Leibovitz's 15 medium (Gibco), $20.2 \mathrm{~g} \mathrm{l}^{-1} \mathrm{NaCl}, 0.54 \mathrm{~g} \mathrm{l}^{-1} \mathrm{KCl}, 0.60 \mathrm{~g} \mathrm{l}^{-1}$ $\mathrm{CaCl}_{2}, 1 \mathrm{~g} \mathrm{l}^{-1} \mathrm{MgSO}_{4}, 3.9 \mathrm{~g} \mathrm{l}^{-1} \mathrm{MgCl}_{2}, 2 \mathrm{mmol} \mathrm{l}^{-1}$ glutamine (Sigma), $100 \mathrm{U} \mathrm{ml}^{-1}$ penicillin (Sigma), and $100 \mu \mathrm{g} \mathrm{ml}^{-1}$ streptomycin (Sigma). The different media used are summarized in Table 1. Hemolymph was seeded $\left(0.2 \mathrm{ml} ; 5 \times 10^{4}\right.$ cells) onto each of the 24 well plates with $0.5 \mathrm{ml}$ BM-L15 and supplements

Table 1. Characteristics of different media for culturing primary hemocytes of Chlamys farreri. The composition of BM-L15 medium is given in 'Materials and methods'; FBS: fetal bovine serum, CFS: $C$. farreri serum. Cell confluence time is the elapsed time between seeding of primary hemocytes and formation of a monolayer. Living cells (\% of total cells) were measured $24 \mathrm{~h}$ after seeding. Cell longevity is the elapsed time until $\sim 50 \%$ of cells were still alive. '-' indicates primary hemocytes did not form cell confluence. Data are given as means $\pm \mathrm{SD}$

\begin{tabular}{|lcccc|}
\hline Group & $\begin{array}{c}\text { Medium } \\
\text { (v/v) }\end{array}$ & $\begin{array}{c}\text { Cell confluence } \\
\text { time (h) }\end{array}$ & $\begin{array}{c}\text { Living } \\
\text { cells (\%) }\end{array}$ & $\begin{array}{c}\text { Cell } \\
\text { longevity (d) }\end{array}$ \\
\hline 1 & BM-L15 & - & $60 \pm 5$ & $3 \pm 2$ \\
2 & BM-L15 + 2\% FBS & $72-96$ & $73 \pm 4$ & $7 \pm 3$ \\
3 & BM-L15 + 5\% FBS & $48-60$ & $86 \pm 5$ & $12 \pm 3$ \\
4 & BM-L15 + 10\% FBS & $60-72$ & $85 \pm 3$ & $10 \pm 3$ \\
5 & BM-L15 + 5\% FBS + 1\% CFS & $8-12$ & $98 \pm 1$ & $48 \pm 4$ \\
6 & BM-L15 + 5\% FBS + 2\% CFS & $8-12$ & $97 \pm 2$ & $45 \pm 3$ \\
7 & BM-L15 + 5\% FBS + 5\% CFS & $12-24$ & $96 \pm 1$ & $40 \pm 3$ \\
\hline
\end{tabular}


(Table 1), and 3 wells were employed for each group. The primary culture was conducted in an SHP-080 biochemistry incubator at $23^{\circ} \mathrm{C}$. The cultured cells were observed and photographed daily using a TS100 inverted microscope (Nikon). The cultured cells were digested with $0.25 \%$ trypsase at primary culture for $24 \mathrm{~h}$ and counted using a hemocytometer after staining with Trypan blue (Cao et al. 2003) to determine the percentage of living cells (Table 1).

\section{Primary culture of hemocytes}

Hemolymph was collected from adductor muscle of C. farreri with a $1 \mathrm{ml}$ syringe, and seeded $(0.5 \mathrm{ml}$; $1.25 \times 10^{5}$ cells) onto a $60 \mathrm{~mm}$ diameter plastic Petri dish containing $0.5 \mathrm{ml}$ CF-L15 medium which consisted of BM-L15 medium supplemented with $5 \%$ FBS and $1 \%$ CFS. The culture was conducted according to the method described above. The CFL15 medium ( $\mathrm{pH} 7.2-7.4)$ was refreshed at intervals of 2 to $3 \mathrm{~d}$ during the primary culture, and the cells were monitored and photographed daily using the TS100 inverted microscope.

\section{Giemsa staining}

Giemsa staining was employed to identify types of the cells according to their morphological characteristics. Hemocytes cultured for $3 \mathrm{~d}$ were fixed with $4 \%$ paraformaldehyde (Sigma) for $15 \mathrm{~min}$ and washed twice in phosphate-buffered saline (PBS, pH 7.4), and then stained with Giemsa stain solution (Sigma) for $20 \mathrm{~min}$ and rinsed with distilled water. After airdrying, the samples were examined and photographed with a Nikon E80i microscope. Six $400 \times$ $400 \mathrm{\mu m}^{2}$ sized squares of the samples were randomly selected and observed at 800-fold magnification under the inverted microscope. Cells of different types were counted and their proportions were calculated.

\section{Challenge of primary cultured hemocytes with Vibrio anguillarum}

The Gram-negative bacterium $V$. anguillarum was grown in marine broth $\left(2216 \mathrm{E}\right.$; tryptone $5 \mathrm{~g} \mathrm{l}^{-1}$, yeast extract $1 \mathrm{~g} \mathrm{l}^{-1}, \mathrm{C}_{6} \mathrm{H}_{5} \mathrm{Fe} \cdot 5 \mathrm{H}_{2} \mathrm{O} 0.1 \mathrm{~g} \mathrm{l}^{-1}$, $\left.\mathrm{pH} 7.6\right)$ at $28^{\circ} \mathrm{C}$, and then centrifuged at $2000 \times g(5 \mathrm{~min})$ to harvest the bacteria when the $\mathrm{OD}_{600}$ was 0.2 . The pellet was suspended in PBS and adjusted to $1 \times 10^{5} \mathrm{CFU} \mathrm{ml}^{-1}$. The monolayer hemocytes were cultured in $60 \mathrm{~mm}$ diameter plastic Petri dishes with CF-L15 medium for $12 \mathrm{~h}$. The CF-L15 medium (pH 7.2-7.4, without penicillin and streptomycin) was then refreshed after washing the monolayer hemocytes twice with PBS. Based on pre-experimental data, the hemocytes were challenged using $V$. anguillarum at a multiplicity of infection (MOI) of 0.16 ( 16 bacteria per 100 cells). Phagocytosis by hemocytes was monitored and photographed daily using the TS100 inverted microscope.

\section{Challenge of primary cultured hemocytes with extracellular products (ECPs) of $V$. anguillarum}

ECPs of $V$. anguillarum were produced using the cellophane overlay method as described by Liu et al. (1957). The supernatant containing the ECPs was filtered with a $0.22 \mu \mathrm{m}$ membrane and stored at $-80^{\circ} \mathrm{C}$ until use. The protein concentration of the ECPs was measured using Coomassie brilliant blue staining (Bradford 1976). Three ECP concentrations $(2,20$, and $200 \mu \mathrm{g} \mathrm{ll}^{-1}$ ) were used as treatment groups, and the negative control used the same volume of PBS without ECPs. Monolayer hemocytes cultured in 24well plates with CF-L15 medium for $12 \mathrm{~h}$ were challenged using either the ECPs at different concentrations or the PBS. Three wells were used for each group. These cells were collected using $0.25 \%$ trypsin (Sigma) and centrifugation at $800 \times g$ after being challenged for $3,6,12,24$, or $48 \mathrm{~h}$, and then stored at $-80^{\circ} \mathrm{C}$ for total RNA extraction. Cytopathic effects (CPEs) of ECPs on the hemocytes were observed and photographed using the TS100 inverted microscope during the experiment.

\section{Challenge of primary cultured hemocytes with OsHV-1}

OsHV-1 supernatant was prepared from OsHV-1 positive tissues of Scapharca broughtonii according to the method described by Schikorski et al. (2011). The number of viral DNA copies in the supernatant was examined by quantitative real-time PCR (qRTPCR) according to the method described below. Based on pre-experimental data, monolayer hemocytes cultured in CF-L15 medium for $12 \mathrm{~h}$ were challenged with OsHV-1 at an MOI of 864 (864 viruses cell $^{-1}$ ). PBS and tissue extract of healthy $S$. broughtoni were used as negative controls. After being infected for $0.5 \mathrm{~h}$, the hemocytes were washed twice in PBS and then cultured in $1 \mathrm{ml} \mathrm{CF-L15}$ 
medium. CPEs were observed under the TS100 inverted microscope. To detect virus amplification, some of the hemocytes were collected at 0.5 and $24 \mathrm{~h}$ (when obvious CPE had occurred) after OsHV-1 infection, then stored at $-80^{\circ} \mathrm{C}$ as per the method described above for DNA extraction. Other primary cultured hemocytes were collected and stored at $-80^{\circ} \mathrm{C}$ for $3,6,12,24$, and $48 \mathrm{~h}$ after OsHV-1 infection for total RNA extraction. Others were fixed in $2.5 \%$ glutaraldehyde for transmission electron microscopy.

\section{Transmission electron microscopy (TEM)}

The samples fixed in $2.5 \%$ glutaraldehyde were transferred into $1 \% \mathrm{OsO}_{4}$ for $30 \mathrm{~min}$, then dehydrated in a graded series of acetone $(30,50,70,80$, $100 \%$ ) and embedded in Epon-812. Ultrathin-sections were made with an LKB-8000 ultramicrotome and stained with lead acetate and post-stained with uranyl acetate before examination under TEM (H7000, Hitachi).

\section{DNA extraction and OsHV-1 quantification by qRT-PCR}

Total DNA was extracted from the stored hemocytes described above using the phenol chloroform-sodium dodecyl sulfate method according to Molecular Cloning III (Sambrook 2001). qRT-PCR was carried out with the primers BF/B4 (BF, 5'-GTC GCA TCT TTG GAT TTA ACA A-3'; B4, 5'-ACT GGG ATC CGA CTG ACA AC-3') and the TaqMan probe BP (BP, 6FAM-ATC GGG GGG GGG GGT TTT TTT TTT ATC G-BHQ1). The reaction mixture contained $1 \mu$ of each primer $(20 \mu \mathrm{M}), 1 \mu \mathrm{l}$ of TaqMan probe $(10 \mu \mathrm{M})$, $7 \mu \mathrm{l}$ of water, and $1 \mu \mathrm{l}$ of DNA. The PCR reaction was performed using the method described by Martenot et al. (2010). Triplicate assays were conducted for each DNA sample. The number of OsHV-1 DNA copies was quantified according to the method of Le Deuff \& Renault (1999) by comparing $C_{\mathrm{t}}$ (cycle threshold) values of each sample using the standard curve. The results are presented as the virus DNA copy number per total DNA of the control or treatment group.

\section{RNA isolation and cDNA synthesis}

Total RNA was extracted from the samples stored at $-80^{\circ} \mathrm{C}$ using the thiocyanate-phenol-chloroform method according to Molecular Cloning III (Sambrook
2001), and treated with DNase I to remove genomic DNA. Quality and quantity of the RNA were measured by agarose gel electrophoresis and spectrophotometry at $260 \mathrm{~nm}$. The RNA was reverse-transcribed to cDNA for qRT-PCR analysis according to the protocol of the Prime script cDNA Amplification Kit (Takara).

\section{QM expression levels analyzed by qRT-PCR}

QM (GenBank accession no. AAQ09228) is an immune-related gene which encodes a $60 \mathrm{~S}$ ribosomal subunit protein. Expression levels of QMin the hemocytes after challenge by bacteria or viruses were analyzed through qRT-PCR, which was performed using SYBR Green Real-Time PCR Master Mix (Takara) and an ABI 7500 Real-Time PCR System (Applied Biosystems). Two QM-specific primers (q-QmF: 5'-GAG GAG ATG AGG CAG GAT GG-3' and q-QmR: 5'ACA GTC GCA AGG CAG TAA GA-3') were designed to amplify a $109 \mathrm{bp}$ fragment of C. farreri $Q M$ (Cf-QM) transcript (Chen et al. 2015). Two elongation factor 1a $(E F-1 \alpha)$-specific primers $(E F-1 \alpha \mathrm{F}$ : 5'-ATC CTT CCT CCA TCT CGT CCT-3', EF-1 $\alpha$ R: 5'-GGC ACA GTT CCA ATA CCT CCA-3') were used for an 86 bp fragment of $C$. farreri EF-1 $\alpha$ transcript (GenBank accession no. AEX08674.1) as a reference gene (Ma et al. 2017). Triplicate assays for each cDNA sample were conducted. Data were analyzed by the ABI 7500 system SDS software version 1.4 (Applied Biosystems) with an automatically set baseline and $C_{\mathrm{t}}$ values. Relative $C f$ - $Q M$ mRNA levels were calculated based on the $2^{-\Delta \Delta C_{\mathrm{t}}}$ method.

\section{Statistical analysis}

Unless noted otherwise, all data are presented as means \pm SEM of 3 samples with 3 parallel repetitions. Differences between means were tested using 1-way analysis of variance followed by the least significant difference test with a significance level set at $p<0.05$ by SPSS software version 17.0.

\section{RESULTS}

\section{Optimal medium for culturing primary hemocytes}

When seeded onto different media, Chlamys farreri hemocytes first clustered into cell masses of various sizes on the plate surface, and then formed 
pseudopods and gradually migrated out of the cell masses. Finally, they spread to form cell monolayers (Fig. 1). However, confluence capability and survival time of the cultured hemocytes differed among various media (Table 1). BM-L15 medium could only maintain the survival of $C$. farreri hemocytes ephemerally, and these cells could not adhere well and form a monolayer. FBS improved the confluence and longevity of the hemocytes to some extent, and 5\% FBS was more effective than the other 2 FBS groups. When CFS at different concentrations was added to the medium (BM-L15 with 5\% FBS), cell survival rate was $>96 \%$ when in primary culture for $24 \mathrm{~h}$, and longevity of the primary cells was extended to more than $40 \mathrm{~d}$. Based on these results, the best medium was identified as BM-L15 supplemented with 5\% FBS and $1 \%$ CFS (Table 1). This medium was named CF-L15.

\section{Types and morphological character- istics of primary cultured hemocytes}

When C. farreri hemocytes were primary cultured in CF-L15 medium for $12 \mathrm{~h}$, approximately $90 \pm 2 \%$ (mean $\pm \mathrm{SD}$ ) of primary hemocytes were fibroblast-like (Fig. 1D) and nearly $10 \pm 2 \%$ (mean $\pm \mathrm{SD}$ ) of cells were macrophage-like (Fig. 1D) under inverted microscopy. Giemsa staining showed that fibroblast-like cells contained $25 \pm 3 \%$ (mean \pm SD) granulocytes (Fig. 2B) and 75 $\pm 4 \%$ (mean \pm SD) hyalinocytes (Fig. 2A).

\section{Phagocytosis of Vibrio anguillarum by primary cultured hemocytes}

Phagocytosis by the primary hemocytes could be observed using the inverted microscope (Fig. 3). V. anguillarum was first observed in the margin of primary cultured hemocytes after infection for $6 \mathrm{~h}$ (Fig. 3A,B). With extension of the challenge time, the number of bacteria phagocytosed by each hemocyte cell increased from $7 \pm 2$ $($ means $\pm \mathrm{SD})$ to $26 \pm 5$ (means $\pm \mathrm{SD})(\mathrm{n}=6)$, and these bacteria were located in the margin or center of hemocytes infected for $12 \mathrm{~h}$ (Fig. 3C,D).
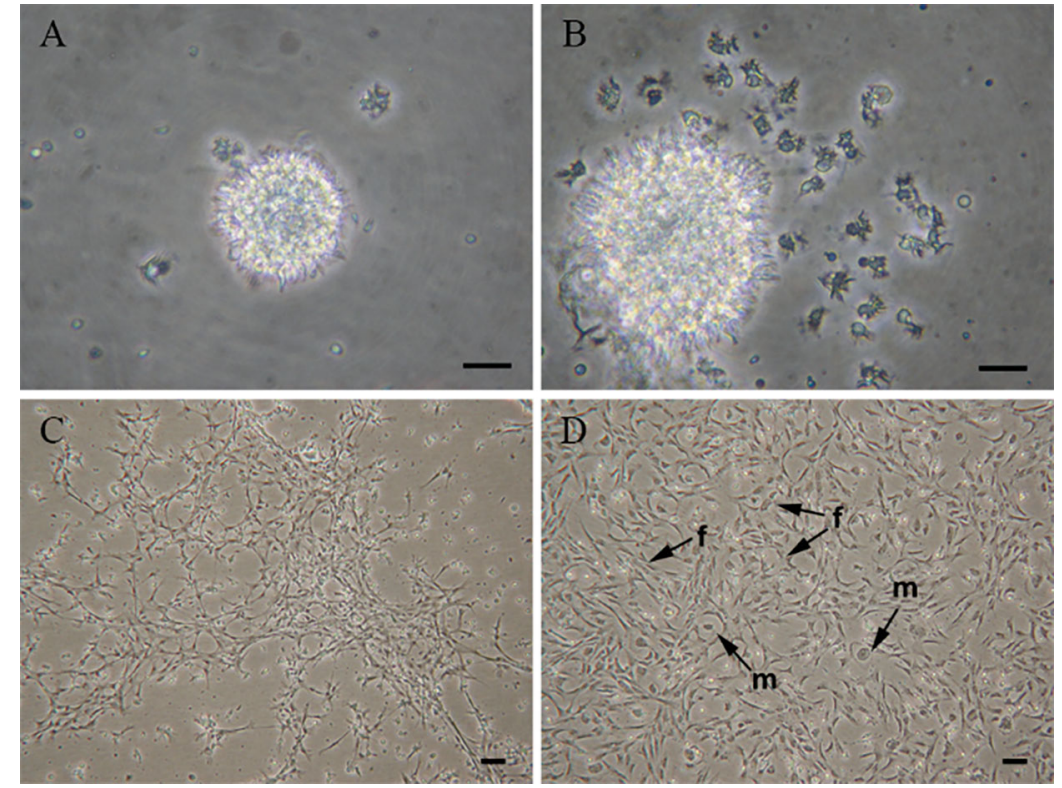

Fig. 1. Photomicrograph of Chlamys farreri primary hemocytes in CF-L15 medium at (A) $0 \mathrm{~h}$, (B) $4 \mathrm{~h},(\mathrm{C}) 8 \mathrm{~h}$, and (D) $12 \mathrm{~h}$. f: fibroblast-like hemocytes; $\mathrm{m}$ : macrophage-like hemocytes. Scale bars $=20 \mu \mathrm{m}$

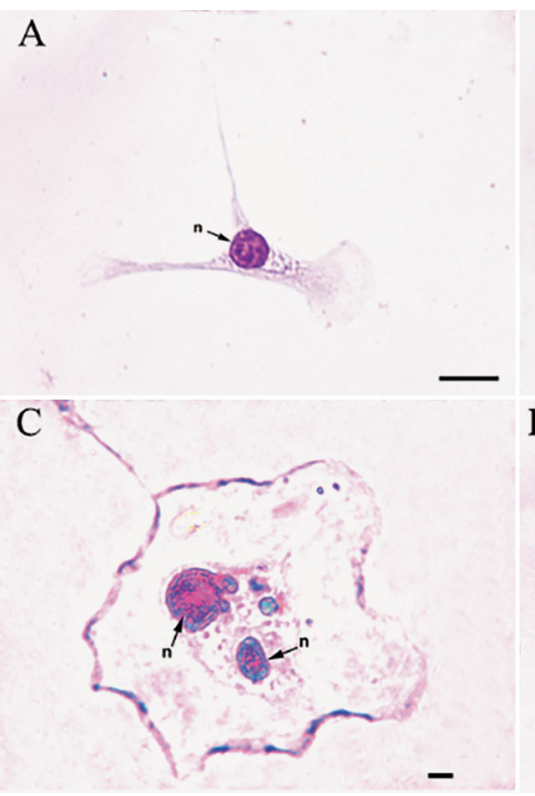

B

D

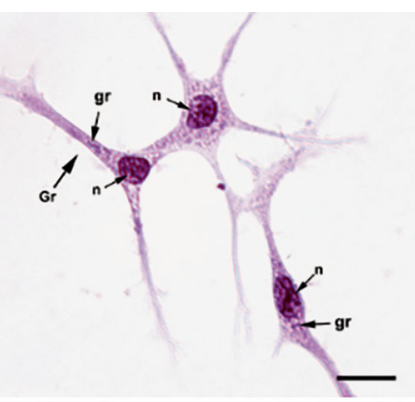

Fig. 2. Photomicrograph of Chlamys farreri hemocytes in CF-L15 medium (Giemsa stain). (A) Hyalinocyte; (B) granulocytes; (C,D) macrophage-like cells. gr: granules; $\mathrm{n}$ : nucleus. Scale bars $=10 \mu \mathrm{m}$ 

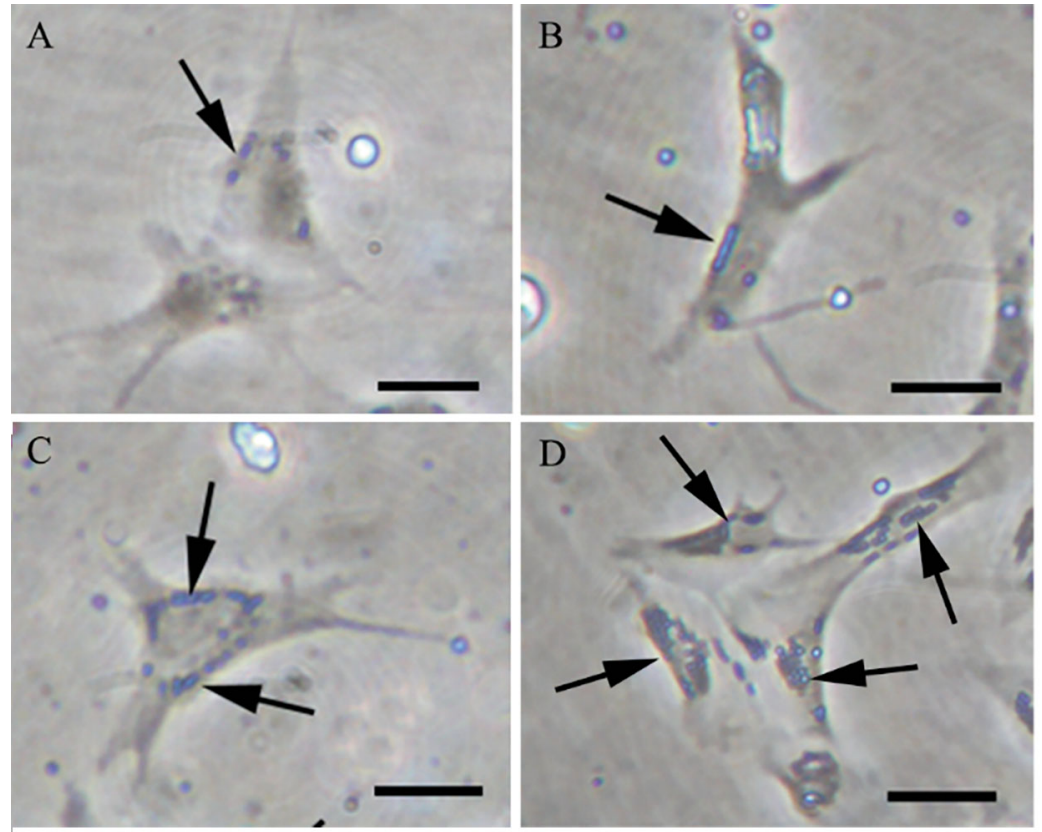

Fig. 3. Primary cultured Chlamys farreri hemocyte phagocytosing Vibrio anguillarum. Primary hemocytes infected for $(A, B) 6 \mathrm{~h}$ and $(\mathrm{C}, \mathrm{D}) 12 \mathrm{~h}$. Black arrows show $V$. anguillarum. Scale bars $=20 \mu \mathrm{m}$

\section{CPEs of $V$. anguillarum ECPs on primary cultured hemocytes}

When $C$. farreri primary hemocytes were challenged using ECPs of $V$. anguillarum at concentrations of 2 and $20 \mu \mathrm{g} \mathrm{pl}^{-1}$, no obvious cytotoxicity was presented (Fig. 4B,C). However, hemocyte cytotoxicity was observed at $200 \mu \mathrm{g} \mathrm{rl}^{-1}$ ECPs after the hemocytes were challenged for $12 \mathrm{~h}$. Under inverted microscopy, the morphology of the challenged hemocytes changed from fibroblast-like into rounded and shrunken cells (Fig. 4D). Moreover, these cells gradually lost their adhesion properties, and ultimately the cell monolayer was destroyed (Fig. 4D).

\section{Infection and replication of OsHV-1 in primary hemocytes}

The number of viral DNA copies was estimated to be approximately 5.4 $\times 10^{5}$ in $1 \mu \mathrm{l}$ of OsHV-1 supernatant by qRT-PCR. After the primary cultured hemocytes were infected with OsHV1 for $24 \mathrm{~h}$, apparent CPE was observed in the cells (Fig. 5E). These infected cells initially exhibited shrinkage or aggregated, and then most of the infected cells became more rounded at $48 \mathrm{~h}$ post incubation (Fig. 5F). Finally, the cell monolayer completely detached from the culture dishes or broke up at $5 \mathrm{~d}$ post incubation. In contrast, no obvious CPE was observed in cells that were inoculated with the same volume of PBS and tissue extract of healthy Scapharca broughtonii (Fig. 5A-D).

qRT-PCR revealed that the number of OsHV-1 DNA copies in the primary hemocytes infected for $24 \mathrm{~h}$ was significantly higher (by ca. 7-fold) than that at $0.5 \mathrm{~h}$ post infection (Fig. 6). Meanwhile, no OsHV-1 DNA was detected in the hemocytes of the PBS group or in tissue extract of the healthy $S$. broughtonii group. Furthermore, TEM revealed OsHV-1 particles in the nucleus of primary cultured hemocytes infected for $48 \mathrm{~h}$ (Fig. 7A). In the infected primary cells, the karyotheca of some nuclei were incomplete (Fig. 7A) or were in karyolysis. Intra-nuclear empty capsids and nucleocapsids were observed in primary cultured hemocytes (Fig. 7B). The nucleocapsids which contained an electron-
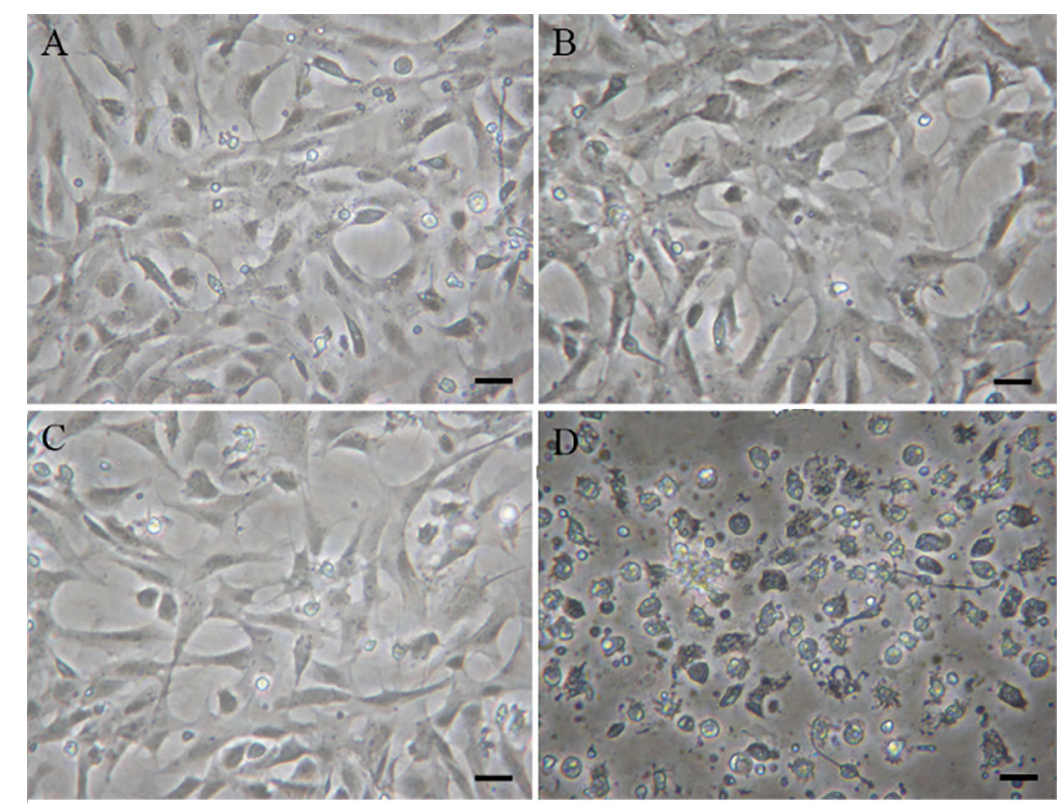

Fig. 4. Morphologic features of primary cultured Chlamys farreri hemocytes after challenge with extracellular products (ECPs) of Vibrio anguillarum for $12 \mathrm{~h}$ at different concentrations. (A) Phosphate-buffered saline (control), and ECPs at (B) $2 \mu \mathrm{g} \mathrm{l}^{-1}$, (C) $20 \mu \mathrm{g} \mathrm{l}^{-1}$, and (D) $200 \mu \mathrm{g} \mu \mathrm{l}^{-1}$. Scale bars $=20 \mu \mathrm{m}$ 

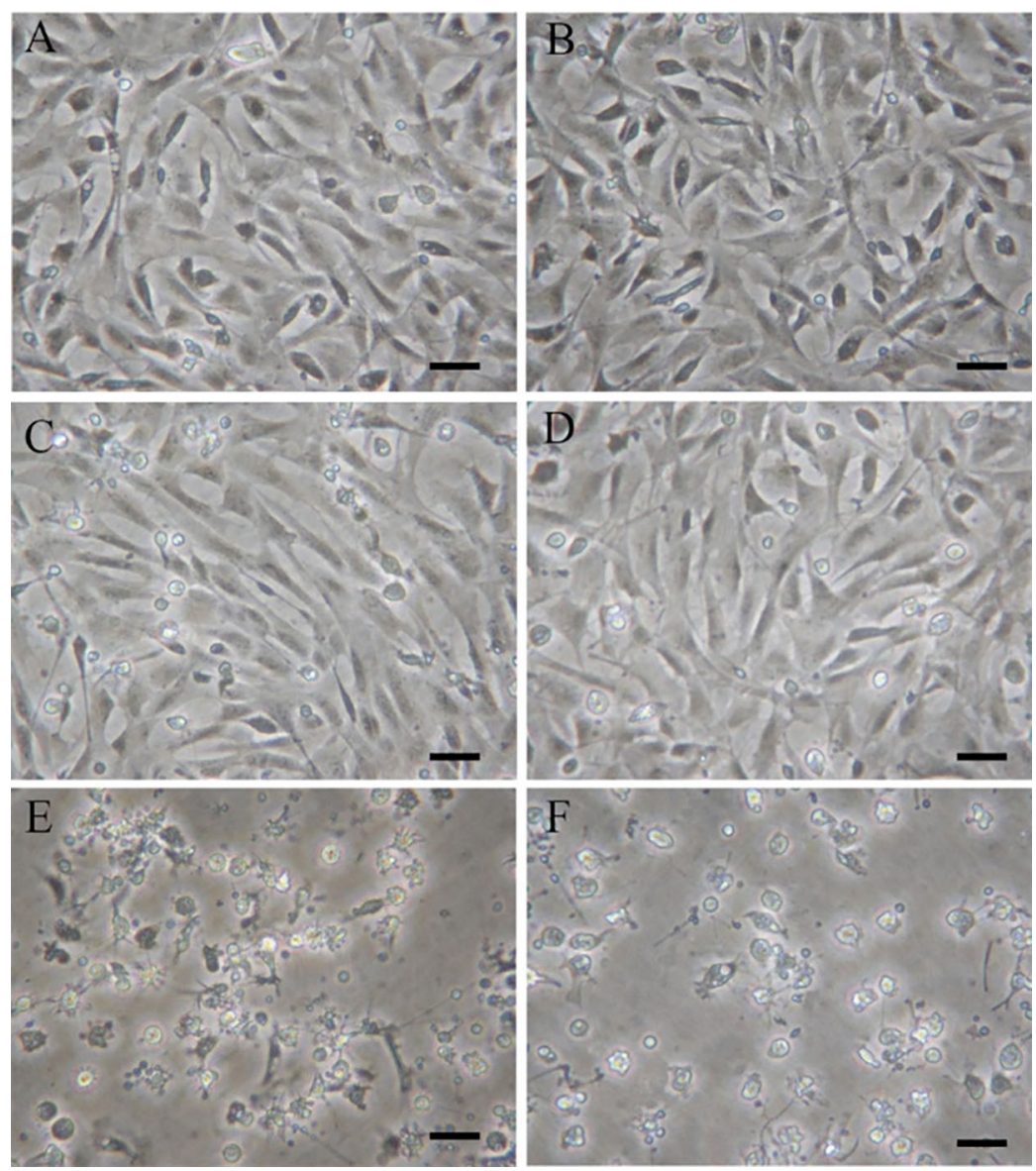

Fig. 5. Morphologic features of Chlamys farreri hemocytes challenged with OsHV-1 virus. (A) Phosphate-buffered saline (PBS), $24 h_{i}$ (B) PBS, $48 h_{\text {; }}$ (C) tissue extract of healthy Scapharca broughtonii, $24 \mathrm{~h}_{i}$ (D) tissue extract of healthy S. broughtonii, 48 h; (E) OsHV-1, $24 h_{i}($ F) OsHV-1, 48 h. Scale bars $=20 \mu \mathrm{m}$

dense core were polygonal in shape and 130-150 nm in diameter (Fig. 7B).

\section{Expression of $C f-Q M$ in primary hemo- cytes challenged by bacteria and viruses}

The level of $C f$-QMmRNA showed a slight increase in primary hemocytes before the challenge with ECPs of $V$. anguillarum for $6 \mathrm{~h}$, while a significant increase of $C f$-QM mRNA level occurred at $12 \mathrm{~h}$, which was about 2.5-fold higher than that of the control. After that, it decreased significantly to the level of the control (Fig. 8).

The $C f-Q M$ expression level also increased significantly in primary hemocytes challenged with OsHV-1 viruses for $12 \mathrm{~h}$, to about 2-fold higher than that of the control at the same time. It then reached a peak at

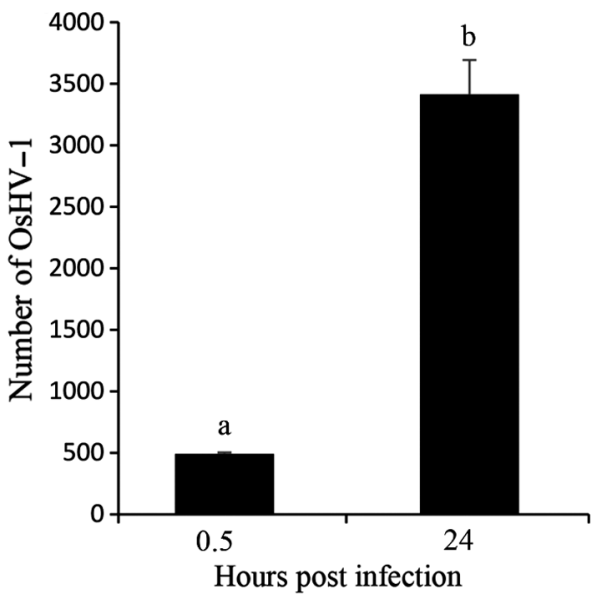

Fig. 6. Number of virus particles in primary Chlamys farreri hemocytes after infection with OsHV-1 virus detected by qRT-PCR. Data are means \pm SEM. different letters indicate significant differences $(p<0.05)$

$24 \mathrm{~h}$, at 4 -fold higher than that of the control, and then decreased significantly to the level of the control at $48 \mathrm{~h}$ (Fig. 9).

\section{DISCUSSION}

\section{Stable primary hemocytes of the scallop Chlamys farreri}

In this study, we established a stable primary culture system for C. farreri hemocytes which adhered rapidly and formed cell monolayers on the plastic Petri dishes, and were maintained for more than $40 \mathrm{~d}$. In this system,
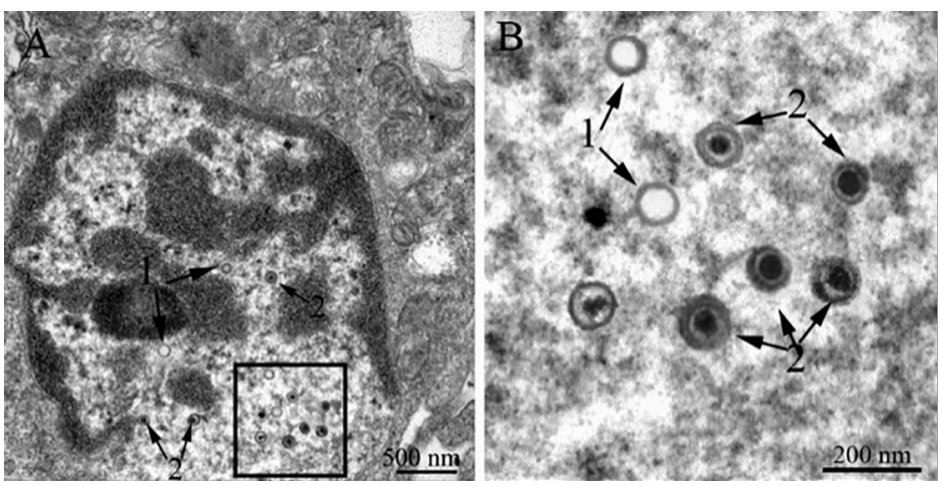

Fig. 7. Transmission electron micrographs of primary Chlamys farreri hemocytes $48 \mathrm{~h}$ after infection with OsHV-1 virus. (A) Primary hemocyte infected with OsHV-1 in its nucleus (n). (B) Higher magnification of the box in Panel $A_{i} 1$ : empty capsids of the OsHV-1 virus; 2: OsHV-1 virus particles 


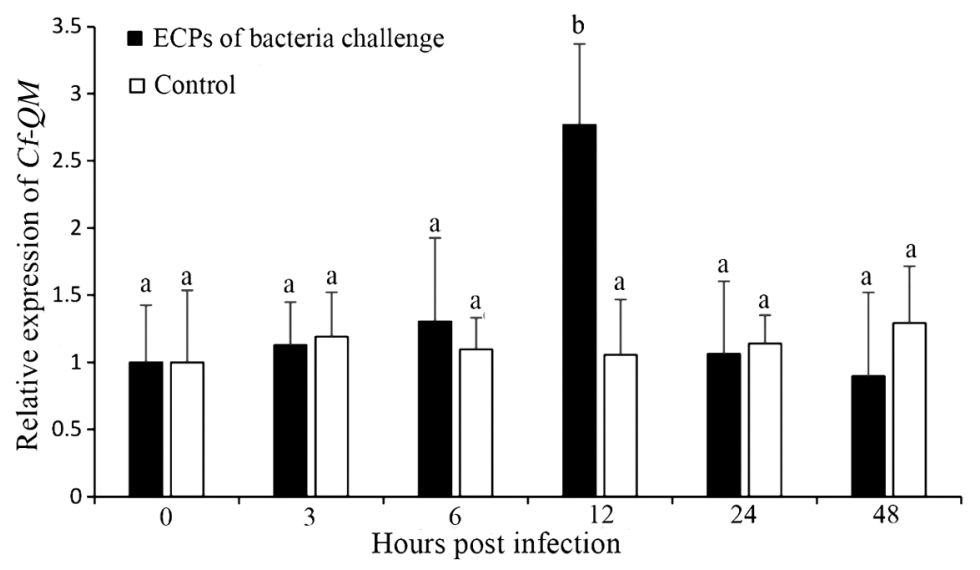

Fig. 8. Relative expression of the $C f$-QM gene in Chlamys farreri hemocytes challenged by extracellular products (ECPs) of Vibrio anguillarum. The level of $C f$-QM mRNA in primary hemocytes of the control group at $0 \mathrm{~h}$ was set as 1.00 to calibrate the relative levels. Data are means $\pm \mathrm{SEM}$; different letters above bars indicate significant differences $(p<0.05)$

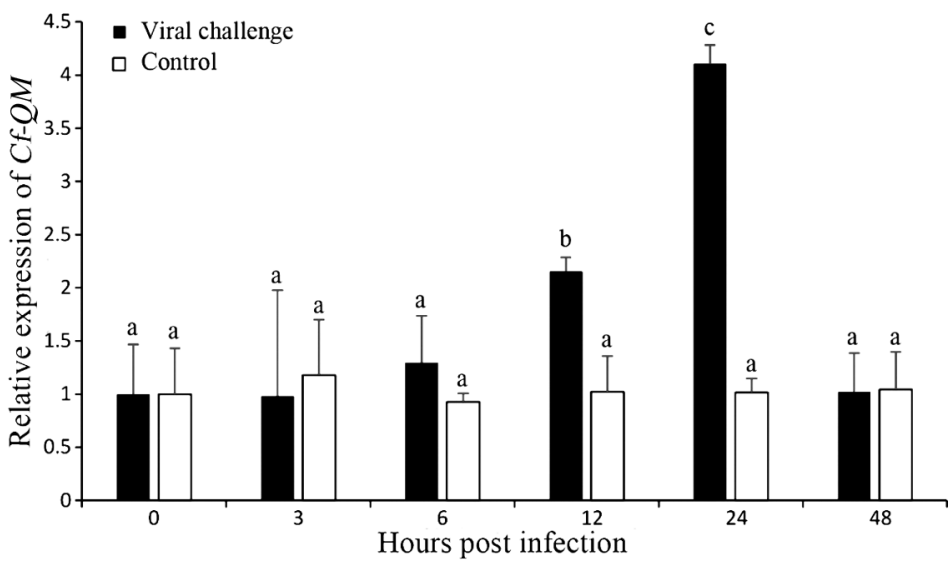

Fig. 9. Relative expression of the Cf-QM gene in Chlamys farreri primary hemocytes challenged with OsHV-1 virus. The level of $C f-Q M$ mRNA in primary hemocytes of the control group at $0 \mathrm{~h}$ was set as 1.00 to calibrate the relative levels. Data are means \pm SEM; different letters above bars indicate significant differences $(\mathrm{p}<0.05)$

FBS and CFS were important factors in improving the confluence ability and longevity of the primary hemocytes. The optimal concentrations were $5 \%$ FBS and $1 \%$ CFS in BM-L15 medium. In previous studies, hemocytes of the abalone Haliotis tuberculata were primary cultured for 7-10 d in Hanks' 199 sterile medium (Lebel et al. 1996, Serpentini et al. 2000, Farcy et al. 2007, Latire et al. 2012), oyster Crassostrea gigas hemocytes were maintained for $7 \mathrm{~d}$ in L-15 medium supplemented with $10 \%$ FBS, and mussel Mytilus galloprovincialis hemocytes were maintained for $20 \mathrm{~d}$ in L-15 medium supplemented with inactivated hemolymph (Domart-
Coulon et al. 1994, Cao et al. 2003). Therefore, the concentration of FBS and the activity of hemolymph seem to have an obvious impact on the survival of primary hemocytes. Furthermore, 3 types of $C$. farreri hemocytes, i.e. hyalinocytes, granulocytes, and macrophagelike cells, were identified in this primary culture, which is similar to that reported by Sun \& Li (2001), indicating that characteristics of the hemocytes are retained.

\section{Primary cultured hemocytes to study host-pathogen interactions and immune-related genes}

Over the past several decades, pathogen infections have occurred frequently, causing mass mortalities of $C$. farreri and seriously affecting the development of the scallop aquaculture industry in China. Therefore, an indepth understanding of the pathogenic mechanisms involving in host-pathogen interactions and immune responses is crucial for sustainable aquaculture (Wang et al. 2012a). To date, many researchers have focused on studying the pathogenicity of bacteria and viruses to $C$. farreri in vivo (Wang et al. 2004, Zhang et al. 2006, Sun et al. 2014, Chen et al. 2015). However, in vivo experiments retain some deficiencies, including a long experimental period and high cost. In this study, an in vitro approach was shown to be useful for studying hostpathogen interactions in C. farreri. We challenged the primary cultured hemocytes with Vibrio anguillarum and observed the process of the bacteria being phagocytosed by hemocytes. Moreover, cytoxic effects of $V$. anguillarum ECPs appeared on the primary hemocytes of $C$. farreri (Figs. 4 \& 8), which is similar to that of $V$. aestuarianus in the hemocytes of the oyster C. gigas on cellular and molecular levels in vivo (Labreuche et al. 2006). Furthermore, we revealed that the primary cultured hemocytes of $C$. farreri were highly susceptible to OsHV-1 viruses from Scapharca broughtonii, in which the typical CPE appeared and virus replication took place (Figs. 5-7 \& 9). These data indicated that the primary hemocytes of C. farreri can be used to study pathogenic mechanisms, such as the processes of bacterial infection, isolation and propagation of viruses, and identification and function of immunerelated genes in shellfish. 
Acknowledgements. This study was supported by the Scientific and Technological Innovation Project from the Laboratory for Marine Fisheries and Aquaculture, Qingdao National Laboratory for Marine Science and Technology (2015ASKJ02), and the National High Technology Research and Development Program of China (863 Program) (No. 2012AA10A402).

\section{LITERATURE CITED}

Aladaileh S, Nair SV, Birch D, Raftos DA (2007) Sydney rock oyster (Saccostrea glomerata) hemocytes: morphology and function. J Invertebr Pathol 96:48-63

* Astuya A, Carrera C, Ulloa V, Aballay A, Núñez-Acuña G, Hégaret H, Gallardo-Escárate C (2015) Saxitoxin modulates immunological parameters and gene transcription in Mytilus chilensis hemocytes. Int J Mol Sci 16: 15235-15250

* Bai C, Wang C, Xia J, Sun H, Zhang S, Huang J (2015) Emerging and endemic types of Ostreid herpesvirus 1 were detected in bivalves in China. J Invertebr Pathol 124:98-106

Barbosa Solomieu V, Renault T, Travers MA (2015) Mass mortality in bivalves and the intricate case of the Pacific oyster, Crassostrea gigas. J Invertebr Pathol 131:2-10

* Binelli A, Cogni D, Parolini M, Riva C, Provini A (2009a) In vivo experiments for the evaluation of genotoxic and cytotoxic effects of Triclosan in zebra mussel hemocytes. Aquat Toxicol 91:238-244

Binelli A, Cogni D, Parolini M, Riva C, Provini A (2009b) Cytotoxic and genotoxic effects of in vitro exposure to Triclosan and Trimethoprim on zebra mussel (Dreissena polymorpha) hemocytes. Comp Biochem Physiol C Toxicol Pharmacol 150:50-56

Bradford MM (1976) A rapid and sensitive method for the quantitation of microgram quantities of protein utilizing the principle of protein-dye binding. Anal Biochem 72: 248-254

Cai X, Zhang Y (2014) Marine invertebrate cell culture: a decade of development. J Oceanogr 70:405-414

Cao A, Mercado L, Ramos-Martinez JI, Barcia R (2003) Primary cultures of hemocytes from Mytilus galloprovincialis Lmk.: expression of IL-2R $\alpha$ subunit. Aquaculture 216:1-8

Chen SL, Ren GC, Sha ZX, Shi CY (2004) Establishment of a continuous embryonic cell line from Japanese flounder Paralichthys olivaceus for virus isolation. Dis Aquat Org 60:241-246

Chen G, Zhang C, Wang Y, Wang Y, Guo C, Wang C (2015) Molecular characterization and immune response expression of the $Q M$ gene from the scallop Chlamys farreri. Fish Shellfish Immunol 45:543-550

Chu FLE (2000) Defense mechanisms of marine bivalves. In: Fingerman M, Nagabhushanam R (eds) Recent advances in marine biotechnology: immunobiology and pathology. Science Publishers, Enfield, NH, p 1-42

Cima F, Matozzo V, Marin MG, Ballarin L (2000) Haemocytes of the clam Tapes philippinarum (Adams \& Reeve, 1850): morphofunctional characterisation. Fish Shellfish Immunol 10:677-693

* Davison AJ, Trus BL, Cheng N, Steven AC and others (2005) A novel class of herpesvirus with bivalve hosts. J Gen Virol 86:41-53

Davison AJ, Eberle R, Ehlers B, Hayward GS and others (2009) The order Herpesvirales. Arch Virol 154:171-177
* Domart-Coulon I, Doumenc D, Auzouxbordenave S, Le FY (1994) Identification of media supplements that improve the viability of primarily cell cultures of Crassostrea gigas oysters. Cytotechnology 16:109-120

* Donaghy L, Kim BK, Hong HK, Park HS, Choi KS (2009) Flow cytometry studies on the populations and immune parameters of the hemocytes of the Suminoe oyster, Crassostrea ariakensis. Fish Shellfish Immunol 27: 296-301

EFSA (European Food Safety Association) (2010) Scientific opinion on the increased mortality events in Pacific oysters, Crassostrea gigas. EFSA J 8:1894-1954

Farcy E, Serpentini A, Fiévet B, Lebel JM (2007) Identification of cDNAs encoding HSP70 and HSP90 in the abalone Haliotis tuberculata: transcriptional induction in response to thermal stress in hemocyte primary culture. Comp Biochem Physiol B Biochem Mol Biol 146:540-550

*Fryer JL, Lannan CN, Giovannoni SJ, Wood ND (1992) Piscirickettsia salmonis gen. nov., sp. nov., the causative agent of an epizootic disease in salmonid fishes. Int J Syst Bacteriol 42:120-126

* Gong J, Huang Y, Huang X, Ouyang Z, Guo M, Qin Q (2011) Establishment and characterization of a new cell line derived from kidney of grouper, Epinephelus akaara (Temminck \& Schlegel), susceptible to Singapore grouper iridovirus (SGIV). J Fish Dis 34:677-686

*Han Q, Li P, Lu X, Guo Z, Guo H (2013) Improved primary cell culture and subculture of lymphoid organs of the greasyback shrimp Metapenaeus ensis. Aquaculture 410-411:101-113

*Hasoon MF, Daud HM, Abdullah AA, Arshad SS, Bejo HM (2011) Development and partial characterization of new marine cell line from brain of Asian sea bass Lates calcarifer for virus isolation. In Vitro Cell Dev Biol Anim 47: $16-25$

Hine P (1999) The inter-relationships of bivalve haemocytes. Fish Shellfish Immunol 9:367-385

Kabreuche Y, Lambert C, Soudant P, Boulo V, Huvet A, Nicolas JL (2006) Cellular and molecular hemocyte responses of the Pacific oyster, Crassostrea gigas, following bacterial infection with Vibrio aestuarianus strain 01/32. Microbes Infect 8:2715-2724

Lambert C, Soudant P, Choquet G, Paillard C (2003) Measurement of Crassostrea gigas hemocyte oxidative metabolism by flow cytometry and the inhibiting capacity of pathogenic vibrios. Fish Shellfish Immunol 15: 225-240

* Lambert C, Soudant P, Jegaden M, Delaporte M, Labreuche Y, Moal J, Samain JF (2007) In vitro modulation of reactive oxygen and nitrogen intermediate (ROI/RNI) production in Crassostrea gigas hemocytes. Aquaculture 270:413-421

* Latire T, Le Pabic C, Mottin E, Mottier A and others (2012) Responses of primary cultured haemocytes from the marine gastropod Haliotis tuberculata under 10-day exposure to cadmium chloride. Aquat Toxicol 109: 213-221

*LLe Deuff RM, Renault T (1999) Purification and partial genome characterization of a herpes-like virus infecting the Japanese oyster, Crassostrea gigas. J Gen Virol 80: 1317-1322

Kebel JM, Giard W, Favrel P, Boucaud-Camou E (1996) Effects of different vertebrate growth factors on primary cultures of hemocytes from the gastropod mollusc, Haliotis tuberculata. Biol Cell 86:67-72 
Li W, Nguyen VT, Corteel M, Dantas-Lima JJ and others (2014) Characterization of a primary cell culture from lymphoid organ of Litopenaeus vannamei and use for studies on WSSV replication. Aquaculture 433:157-163

Liu PV (1957) Survey of hemolysin production among species of pseudomonads. J Bacteriol 74:718-727

López C, Carballal M, Azevedo C, Villalba A (1997) Morphological characterization of the hemocytes of the clam, Ruditapes decussatus (Mollusca: Bivalvia). J Invertebr Pathol 69:51-57

Ma X, Liang S, Yang D, Ji A, Ma X, Zhang Z (2017) Expression characteristics of Odf3 in gonad are different between Chlamys farreri and vertebrates. J Ocean Univ China 16:121-128

Maeda M, Saitoh H, Mizuki E, Itami T, Ohba M (2004) Replication of white spot syndrome virus in ovarian primary cultures from the kuruma shrimp, Marsupenaeus japonicus. J Virol Methods 116:89-94

Martenot C, Oden E, Travaille E, Malas JP, Houssin M (2010) Comparison of two real-time PCR methods for detection of ostreid herpesvirus 1 in the Pacific oyster Crassostrea gigas. J Virol Methods 170:86-89

Puthumana J, Jose S, Philip R, Singh IB (2015) Cellular and molecular markers in monitoring the fate of lymphoid cell culture from Penaeus monodon Fabricius (1798). Fish Shellfish Immunol 47:893-901

* Renault T, Le Deuff RM, Cochennec N, Chollet B, Maffart P (1995) Herpes-like viruses associated with high mortality levels in larvae and spat of Pacific oysters, Crassostrea gigas: a comparative study, the thermal effects on virus detection in hatchery-reared larvae, reproduction of the disease in axenic larvae. Vet Res 26:539-543

Rinkevich B (2005) Marine invertebrate cell cultures: new millennium trends. Mar Biotechnol 7:429-439

Sambrook J, Russel D (2001) Molecular cloning: a laboratory manual, 3rd edn. Gold Spring Harbor, New York, NY

* Saver MA, Wilkens JL, Syed NI (1999) In situ and in vitro identification and characterization of cardiac ganglion neurons in the crab, Carcinus maenas. J Neurophysiol 81:2964-2976

Schikorski D, Renault T, Saulnier D, Faury N, Moreau P, Pepin J (2011) Experimental infection of Pacific oyster Crassostrea gigas spat by ostreid herpesvirus 1: demonstration of oyster spat susceptibility. Vet Res 42:27

Segarra A, Pépin JF, Arzul I, Morga B, Faury N, Renault T (2010) Detection and description of a particular Ostreid herpesvirus 1 genotype associated with massive mortality outbreaks of Pacific oysters, Crassostrea gigas, in France in 2008. Virus Res 153:92-99

Editorial responsibility: Stephen Feist, Weymouth, UK
Serpentini A, Ghayor C, Poncet JM, Hebert V and others (2000) Collagen study and regulation of the de novo synthesis by IGF-I in hemocytes from the gastropod mollusc, Haliotis tuberculata. J Exp Zool 287:275-284

Sparks A, Morado FJ (1988) Inflammation and wound repair in bivalve molluscs. In: Fisher WS (ed) Disease processes in marine bivalve molluscs. Special Publication 18. American Fisheries Society, Bethesda, MD, p 139-152

* Stepanyan R, Hollins B, Brock SE, McClintock TS (2004) Primary culture of lobster (Homarus americanus) olfactory sensory neurons. Chem Senses 29:179-187

Sun H, Li G (2001) Phagocytosis and scanning electron micrograph of haemocytes Chlamys farreri. High Technol Lett 11:16-19 (in Chinese with English Abstract)

* Sun Z, Yang C, Wang L, Wang X and others (2014) The protein expression profile in hepatopancreas of scallop Chlamys farreri under heat stress and Vibrio anguillarum challenge. Fish Shellfish Immunol 36:252-260

Travers MA, da Silva PM, Le Goïc N, Marie D and others (2008) Morphologic, cytometric and functional characterisation of abalone (Haliotis tuberculata) haemocytes. Fish Shellfish Immunol 24:400-411

Wang CM, Wang XH, Ai HX, Li Y, He GZ, Huang JY (2004) The viral pathogen of massive mortality in Chlamys farreri. Shuichan Xuebao (J Fish China) 28:547-553 (in Chinese with English Abstract)

Wang X, Wang L, Yao C, Qiu L, Zhang H, Zhi Z, Song L (2012a) Alternation of immune parameters and cellular energy allocation of Chlamys farreri under ammonia-N exposure and Vibrio anguillarum challenge. Fish Shellfish Immunol 32:741-749

*Wang X, Wang L, Zhang H, Ji Q and others (2012b) Immune response and energy metabolism of Chlamys farreri under Vibrio anguillarum challenge and high temperature exposure. Fish Shellfish Immunol 33:1016-1026

* Yoshino TP, Bickham U, Bayne CJ (2013) Molluscan cells in culture: primary cell cultures and cell lines. Can J Zool 91:391-404

* Zhang B, Wang X, Sha Z, Yang C, Liu S, Wang N, Chen SL (2011) Establishment and characterization of a testicular cell line from the half-smooth tongue sole, Cynoglossus semilaevis. Int J Biol Sci 7:452-459

Zhang WZ, Wu XZ, Sun JF, Li DF (2006) Epizootiological study on mass mortality of the cultured scallop Chlamys farreri. Acta Oceanol Sin 28:90-100

K Zhou Z, Wang L, Shi X, Zhang H and others (2011) The modulation of catecholamines to the immune response against bacteria Vibrio anguillarum challenge in scallop Chlamys farreri. Fish Shellfish Immunol 31:1065-1071

Submitted: January 16, 2017; Accepted: May 30, 2017 Proofs received from author(s): July 18, 2017 